\title{
Kilka uwag na temat interpretacji przepisów dotyczących koordynacji systemów zabezpieczenia społecznego oraz stosowania wyroków TSUE w zakresie delegowania pracowników
}

\section{Uwagi ogólne}

Prawna instytucja delegowania pracowników do wykonywania pra$\int$ cy na terytorium innego państwa członkowskiego stanowi wyjątek od generalnej reguły podlegania ustawodawstwu państwa wykonywania pracy/prowadzenia działalności. Mimo więc, że praca jest wykonywana $\mathrm{w}$ innym państwie członkowskim, ustawodawstwem właściwym jest prawo państwa, z którego nastąpiło oddelegowanie. Występujące w praktyce przypadki aktywności przedsiębiorców na terytorium więcej aniżeli jednego państwa członkowskiego, sprawiaja że wraz ze świadczonymi przez nich usługami konieczne jest zaangażowanie do ich wykonywania odpowiedniego personelu, który zazwyczaj jest delegowany przejściowo na terytorium państwa, w którym wykonywana jest dana usługa. Prima facie mogłoby się wydawać, że instytucja delegowania jest w praktyce stosowana w celu wykorzystywania różnic pomiędzy obciążeniami socjalnymi różnych państw członkowskich (a zatem personel będzie delegowany z kraju o niższych obciążeniach do kraju, w którym obciążenia są wyższe). Takie przypadki faktycznie się zdarzają. Nie mniejszą aktywność w zakresie delegowania odnotowuje się również z państw, w których obciążenia są większe, do państw o niższych obciążeniach socjalnych. Wówczas nie chodzi jednak o oszczędności na ubezpieczeniu społecznym, ale o delegowanie

* Dr hab., prof. UAM, kierownik Katedry Prawa Pracy i Prawa Socjalnego, Wydział Prawa i Administracji Uniwersytetu im. Adama Mickiewicza w Poznaniu. 
własnych pracowników, bez których realizacja usługi za granicą nie będzie możliwa, bądź też o ochronę własnych interesów (np. know-how).

Analiza spraw dotyczących koordynacji systemów zabezpieczenia społecznego, które były rozpoznawane przez SN, jak i sądy powszechne od chwili przystąpienia Polski do UE dowodzi, że najwięcej uwagi poświęcano problematyce ustalania ustawodawstwa właściwego. Po 11 latach stosowania przepisów unijnej koordynacji, w tym po pięciu latach funkcjonowania rozporządzeń $883 / 2004^{1}$ i $987 / 2009^{2}$, jest ona nadal aktualna i nie wszystkie kwestie można uznać za dostatecznie wyjaśnione. W niniejszym opracowaniu uwaga zostanie skoncentrowana na dwóch zagadnieniach dotyczących delegowania do wykonywania pracy na terytorium innego państwa członkowskiego, w szerszym aspekcie ustalania ustawodawstwa właściwego ${ }^{3}$. Pierwsze koncentruje się wokół dopuszczalności delegowania zleceniobiorców. Drugie wymaga podjęcia rozważań na temat ustalenia normatywnej treści „prowadzenia normalnej działalności" w rozumieniu art. 12 ust. 1 rozp. 883/2004.

\section{Delegowanie zleceniobiorców}

Kwestia związana z delegowaniem zleceniobiorców, jak na razie nie pojawiła się ani $\mathrm{w}$ praktyce stosowania przepisów unijnej koordynacji przez instytucję właściwa, ani w postępowaniach odwoławczych. ZUS nie ma bowiem wątpliwości, że zaświadczenie A1 może zostać wydane również dla osoby zatrudnionej na podstawie zlecenia. Tymczasem problem związany z różną kwalifikacją pracy świadczonej w poszczególnych państwach członkowskich jest znany od dawna zarówno w doktrynie europejskiego prawa socjalnego ${ }^{4}$, jak i orzecznictwie TSUE ${ }^{5} \mathrm{~W}$ istocie sprowa-

${ }^{1}$ Rozporządzenie Parlamentu Europejskiego i Rady (WE) nr 883/2004 z dnia 29 kwietnia 2004 r. w sprawie koordynacji systemów zabezpieczenia społecznego (DzU UE L, 2004.166.1 z późn. zm.); dalej: rozp. 883/2004.

${ }^{2}$ Rozporządzenie Parlamentu Europejskiego i Rady (WE) nr 987/2009 z dnia 16 września 2009 r. dotyczące wykonywania rozporządzenia (WE) nr 883/2004 w sprawie koordynacji systemów zabezpieczenia społecznego (DzU UE L, 2009.284.1 z późn. zm.); dalej: rozp. 987/2009.

${ }^{3}$ Kwestie te były częściowo poruszane w piśmiennictwie: K. Ślebzak, Podleganie ubezpieczeniu społecznemu w przypadku jednoczesnego wykonywania pracy i prowadzenia działalności gospodarczej na terytorium więcej aniżeli jednego państwa członkowskiego UE, „Praca i Zabezpieczenie Społeczne" 2013, nr 11; idem, Kilka uwag na temat procedury ustalania ustawodawstwa właściwego w kontekście delegowania pracowników oraz wykonywania pracy na terytorium więcej aniżeli jednego państwa członkowskiego, „Ubezpieczenia społeczne. Teoria i Praktyka” 2013, nr 12; idem, Determination of the legislation applicable and the principle of being subject to the legislation of a single member state - selected issues, "Ius Novum” 2014, nr 2; idem, Ustalanie ustawodawstwa tymczasowego na podstawie rozporządzeń 883/2004 i 987/2009, „Praca i Zabezpieczenie Społeczne” 2014, nr 7.

${ }^{4}$ H.D. Steinmeyer w: M. Fuchs, Europäisches Sozialrecht, Baden-Baden 2010, s. 160.

5 Wyrok TSUE z dnia 30 marca 2000 r., C-178/97, Banks; z dnia 30 stycznia 1997 r., C-340/94, de Jaeck. 
dza się on do właściwego zdefiniowania takich pojęć, jak praca najemna czy prowadzenie działalności na własny rachunek. Najlepiej kwestię tę ilustrują poszczególne wersje językowe unijnych rozporządzeń. Przykładowo wskazać można na definicję legalną pracy najemnej (art. 1 lit. a rozp. 883/2004). W obcojęzycznych wersjach pojęcie pracy najemnej odpowiada terminowi: Beschäftigung, activity as an employed person, werkzaamheden in loondienst, zaměstnáním, activité salariée czy lønnet beskoftigelse. Wyraźny jest zatem brak zgodności w poszczególnych tłumaczeniach, co wynika przede wszystkim z faktu, że kwestię uznania danej osoby za pracownika w rozumieniu przepisów koordynacyjnych pozostawiono ustawodawstwom poszczególnych państw członkowskich ${ }^{6}$. Za takim rozwiązaniem opowiedział się wcześniej TSUE7. Znalazło to również odzwierciedlenie w treści art. 1 lit. a rozp. 883/2004 („praca najemna” oznacza wszelką pracę lub sytuację równoważna, traktowaną jako taka do celów stosowania ustawodawstwa w zakresie zabezpieczenia społecznego Państwa Członkowskiego, w którym taka praca lub sytuacja równoważna zachodzi), chociaż w doktrynie wskazywano, że lepszym rozwiązaniem byłaby przynajmniej częściowa harmonizacja prawa zabezpieczenia społecznego ${ }^{8}$.

Mimo pozostawienia prawodawcom państw członkowskich znacznej swobody $\mathrm{w}$ zakresie ustalenia, kto może być pracownikiem najemnym w rozumieniu przepisów unijnej koordynacji, trzeba jednak zwrócić uwagę na treść poszczególnych przepisów tych aktów prawnych. Wydaje się bowiem, że zawarte są w nich pewne ograniczenia. Co więcej rozumienie poszczególnych regulacji $\mathrm{w}$ kontekście znajdujących zastosowanie przepisów prawa krajowego mogłoby przesądzać o określonej kwalifikacji pracy wykonywanej przez daną osobę. Jako przykład wskazać można art. 12 ust. 1 rozp. 883/2004 oraz odpowiednie przepisy rozporządzenia wykonawczego, w którym definiuje się pracownika delegowanego. W świetle wskazanych tam przesłanek można odnieść wrażenie, że pracownikiem delegowanym $\mathrm{w}$ rozumieniu rozporządzeń może być $\mathrm{w}$ prawodawstwie polskim wyłącznie osoba zatrudniona na podstawie stosunku pracy. Zgodnie z art. 12 ust. 1 rozp. 883/2004, osoba która wykonuje działalność jako pracownik najemny w państwie członkowskim w imieniu pracodawcy, który normalnie tam prowadzi swą działalność, a która jest delegowana przez tego pracodawcę do innego państwa członkowskiego do wykonywania pracy w imieniu tego pracodawcy nadal podlega ustawodawstwu pierwszego państwa członkowskiego - pod warunkiem, że przewidywany czas takiej pracy nie przekracza dwudziestu czterech

${ }^{6}$ Wyrok TSUE z dnia 30 stycznia 1997 r., C-340/94, de Jaeck; wyrok z dnia 30 stycznia 1997 r., C-221/95, Hervein).

${ }^{7}$ De Jaeck (C-340/94).

${ }^{8}$ H.D. Steinmeyer, w: M. Fuchs, Europäisches Sozialrecht... 
miesięcy i że osoba ta nie jest wysyłana po to, aby zastąpić inną osobę. Przesłanki wskazane w tym przepisie zostały skonkretyzowane $\mathrm{w}$ art. 14 rozp. 987/2009 oraz w art. 1 pkt 1 decyzji A2 Komisji Administracyjnej', w której stwierdza się, że pracę uważa się za wykonywaną na rzecz pracodawcy państwa wysyłającego, jeżeli ustalono, że praca ta jest wykonywana dla tego pracodawcy oraz że wciąż istnieje bezpośredni związek między pracownikiem a pracodawca, który go delegował. $Z$ kolei w celu ustalenia, czy taki bezpośredni związek wciąż istnieje, należy uwzględnić szereg elementów, w tym odpowiedzialność za rekrutację, umowę o pracę, wynagrodzenie oraz prawo do określenia charakteru pracy. Z powyższej decyzji wynika zatem, że o możliwości delegowania danej osoby przesądzają dwa podstawowe elementy: wykonywanie pracy na rzecz pracodawcy wysyłającego oraz podporządkowanie pracownika w procesie pracy. W tym świetle można dojść do wniosku, że na podstawie art. 12 ust. 1 rozp. 883/2004 za pracownika delegowanego należałoby na podstawie przepisów prawa polskiego uznać wyłącznie pracownika w rozumieniu art. 2 k.p. Tylko wówczas można potwierdzić istnienie typowej więzi pracowniczej, podporządkowanie w procesie pracy i możliwość wydawania poleceń przez pracodawcę wysyłającego. Z kolei w sytuacji, w której pracownik delegowany przestaje być w jakiejkolwiek dyspozycji pracodawcy wysyłającego, typowa więź pracownicza nawiązywana jest pomiędzy delegowanym pracownikiem a przedsiębiorca, do którego został on oddelegowany. $\mathrm{W}$ ten sposób tworzy się zupełnie odrębny, nowy stosunek prawny, którego kwalifikacja podlega prawu miejsca wykonywania pracy.

Omawiana kwestia pojawiła się pośrednio w wyroku SN z dnia 4 września 2013 r., II UK 28/13 ${ }^{10}$, w którym rozważano delegowanie uczniów do wykonywania pracy na terytorium innego państwa członkowskiego Unii Europejskiej. Sąd Najwyższy stwierdził, że uczniowie gimnazjów, szkół ponadpodstawowych oraz studenci do ukończenia 26. roku życia wykonujący prace na obszarze Rzeczypospolitej Polskiej na podstawie umowy agencyjnej lub umowy zlecenia albo innej umowy o świadczeniu usług, do której zgodnie z k.c. stosuje się przepisy dotyczące zlecenia, nie podlegają obowiązkowo polskim ubezpieczeniom emerytalnemu i rentowemu. Dlatego w okresie delegowania do pracy w innym państwie członkowskim Unii Europejskiej nie są objęci polskim ustawodawstwem w zakresie ubezpieczeń społecznych. Oznacza to zarazem, że nie mogą być oni uznani za pracowników delegowanych, ponieważ nie posiadają tytułu do ubezpieczenia.

${ }^{9}$ Decyzja nr A2 z dnia 12 czerwca 2009 r. dotycząca wykładni art. 12 rozporządzenia Parlamentu Europejskiego i Rady (WE) nr 883/2004 w sprawie ustawodawstwa mającego zastosowanie do pracowników delegowanych i osób wykonujących pracę na własny rachunek, tymczasowo pracujących poza państwem właściwym (DzU UE C, 2010.106.5).

10 „Orzecznictwo Sądu Najwyższego. Izba Cywilna” 2014, nr 6, poz. 86. 


\section{3. "Normalne prowadzenie działalności" przez przedsiębiorcę delegującego}

Kwestia normalnego prowadzenia działalności pojawiła się w orzecznictwie $\mathrm{w}$ dwóch aspektach pozostających ze sobą w ścisłym związku. Pierwszy dotyczy problemu, który SN przedstawił $\mathrm{w}$ postanowieniu z dnia 24 lutego 2015 r. (III UZP 5/15). Pytanie dotyczyło tego, czy prowadzenie normalnej działalności w Polsce przez pracodawcę, który także deleguje pracowników do pracy w innych państwach członkowskich Unii Europejskiej w rozumieniu art. 12 ust. 1 rozp. 883/2004, wymaga oceny wszystkich kryteriów charakteryzujących prowadzenie zazwyczaj znacznej działalności w Polsce, innej niż działalność związana z samym zarządzaniem wewnętrznym, czy też „w najistotniejszym” stopniu zależy od ustalenia co najmniej $25 \%$ proporcji obrotu krajowego w porównaniu z wielkością obrotu uzyskiwanego z kontraktów i pracy delegowanych pracowników. Drugi koncentruje się wokół zagadnienia szerszego ustalenia normatywnej treści „normalnego prowadzenia działalności” w ujęciu art. 12 ust. 1 rozp. 883/2004.

\section{A. Problem $25 \%$ obrotu}

Ocena „normalnego prowadzenia działalności” przez pryzmat wielkości obrotu pojawiła się w orzecznictwie sądowym, w którym SN uznał, że potwierdzenie prowadzenia normalnej działalności przez pracodawcę w państwie oddelegowania wymaga w pierwszej kolejności odwołania się do tego kryterium (wyroki z dnia 16 grudnia 2014 r. [II UK 93/14, II UK 94/14 oraz II UK 95/14], jak i wcześniejsze, to jest z 4 czerwca 2014 r. [II UK 550/13, LEX nr 1478710 oraz II UK 565/13, LEX nr 1475235], 6 sierpnia 2014 r. [II UK 31/14] oraz 14 października 2014 r. [II UK 32/14]). Z kolei z wcześniejszych wyroków z dnia 11 maja 2005 r. (II UK 388/09) oraz 25 maja 2010 r. (I UK 1/10) wynika, że obrót w kraju delegowania nie jest zasadniczym kryterium przesądzającym kwestię, czy przedsiębiorstwo delegujące (agencja pracy tymczasowej) prowadzi znaczną część działalności w kraju delegowania. Argumentacja wynikająca z przedmiotowych rozstrzygnięć została przedstawiona w uzasadnieniu analizowanego postanowienia III UZP 5/15. Stąd nie ma potrzeby powtarzania zawartych tam wywodów. Ustalenie, jakie znaczenie ma kryterium obrotu, związane jest z szerszym aspektem ustalenia normatywnej treści wyrażenia „normalnego prowadzenia działalności" w ujęciu art. 12 ust. 1 rozp. 883/2004, przy czym na potrzeby dalszych rozważań w pierwszej kolejności podjęte zostaną rozważania, czy i ewentualnie jakie znaczenie ma warunek $25 \%$. 
Zgodnie z art. 12 ust. 1 rozp. 883/2004 osoba, która wykonuje działalność jako pracownik najemny w państwie członkowskim $\mathrm{w}$ imieniu pracodawcy, który normalnie prowadzi tam swą działalność, a która jest delegowana przez tego pracodawcę do innego państwa członkowskiego do wykonywania pracy $\mathrm{w}$ imieniu tego pracodawcy, nadal podlega ustawodawstwu pierwszego państwa członkowskiego, pod warunkiem, że przewidywany czas takiej pracy nie przekracza 24 miesięcy i że osoba ta nie jest wysłana, by zastąpić inną delegowaną osobę. Przepisem wykonawczym do art. 12 ust. 1 rozp. 883/2004 jest m.in. art. 14 ust. 2 rozp. 987/2009, który stanowi, że za pracodawcę, który normalnie prowadzi swą działalność, należy rozumieć pracodawcę „zazwyczaj prowadzącego znaczną część działalności, innej niż działalność związana z samym zarządzeniem wewnętrznym, na terytorium państwa członkowskiego, w którym ma swoją siedzibę, z uwzględnieniem wszystkich kryteriów charakteryzujących działalność prowadzoną przez dane przedsiębiorstwo. Odnośne kryteria muszą zostać dopasowane do specyficznych cech każdego pracodawcy i do rzeczywistego charakteru prowadzonej działalności".

Analiza językowa powyższego przepisu nie pozostawia wątpliwości, że przy ocenie, czy pracodawca prowadzi znaczną część działalności, innej niż działalność związana z samym zarządzeniem wewnętrznym, na terytorium państwa członkowskiego, w którym ma swoją siedzibę, należy uwzględniać wszystkie kryteria charakteryzujące jego działalność. Już choćby odwołanie do zaimka „wszystkie” w odniesieniu do kryteriów, jakie należy uwzględniać przy omawianej ocenie, wskazuje, że niemożliwe jest uznanie jednego kryterium za decydujące $w$ tym sensie, że jego niespełnienie zwalnia instytucję właściwą bądź sąd z badania pozostałych cech charakteryzujących działalność prowadzoną przez dane przedsiębiorstwo.

Nie inaczej kwestię tę ujmuje się w decyzji A2 Komisji Administracyjnej. Wskazuje się w niej, że „w celu ustalenia, w razie potrzeby i w razie wątpliwości, czy pracodawca zazwyczaj prowadzi znaczną część działalności na terytorium państwa członkowskiego, w którym ma swoją siedzibę, instytucja właściwa w tym państwie zobowiązana jest zbadać wszystkie [pogr. K.Ś.] kryteria charakteryzujące działalność prowadzoną przez tego pracodawcę, $\mathrm{w}$ tym miejsce, w którym przedsiębiorstwo ma swą zarejestrowaną siedzibę i administrację, liczebność personelu administracyjnego pracującego w państwie członkowskim, w którym pracodawca ma siedzibę, oraz w drugim państwie członkowskim, miejsce, w którym rekrutowani są pracownicy delegowani, i miejsce, w którym zawierana jest większość umów z klientami, prawo mające zastosowanie do umów zawartych przez przedsiębiorstwo z jednej strony z pracownikami i z drugiej strony $z$ klientami, obroty $w$ odpowiednio typowym okresie $w$ każ- 
dym z państw członkowskich, których rzecz dotyczy, oraz liczbę umów wykonanych w państwie wysyłającym. [W przedmiotowej decyzji podkreśla się też, że] wykaz ten nie jest wyczerpujący, ponieważ kryteria powinny być dostosowane do każdego konkretnego przypadku i powinny uwzględniać charakter działalności prowadzonej przez przedsiębiorstwo w państwie, w którym ma ono siedzibę" (pkt 1 decyzji A2).

Podobnie zagadnienie to wyjaśnione zostało w publikacji Komisji Europejskiej pt. Praktyczny poradnik: Ustawodawstwo majace zastosowanie do pracowników w Unii Europejskiej (UE), w Europejskim Obszarze Gospodarczym (EOG) $i$ w Szwajcarii. Stwierdza się w nim, że "fakt prowadzenia znacznej części działalności w państwie delegującym można sprawdzić poprzez szereg obiektywnych czynników, przy czym następujące czynniki są szczególnie istotne. Należy zauważyć, że wykaz ten nie jest wyczerpujący, ponieważ kryteria powinny być dostosowane do każdego konkretnego przypadku i powinny uwzględniać charakter działalności prowadzonej przez przedsiębiorstwo w państwie, w którym ma ono siedzibę. Konieczne może być również uwzględnienie innych kryteriów odpowiednich do określonych cech przedsiębiorstwa i rzeczywistego charakteru działalności przedsiębiorstwa w państwie, w którym ma ono siedzibę: miejsce, w którym delegujące przedsiębiorstwo ma swą zarejestrowaną siedzibę i administrację; liczebność personelu administracyjnego delegującego przedsiębiorstwa pracującego w państwie delegującym i w państwie zatrudnienia - obecność wyłącznie personelu administracyjnego w państwie delegującym wyklucza tym samym możliwość zastosowania do tego przedsiębiorstwa przepisów dotyczących delegowania; miejsce, w którym rekrutowani są pracownicy delegowani; miejsce, w którym zawierana jest większość umów z klientami; prawo mające zastosowanie do umów zawartych przez delegujące przedsiębiorstwo z pracownikami i z klientami; liczba umów wykonanych w państwie delegującym i państwie zatrudnienia; obroty osiągane przez delegujące przedsiębiorstwo $\mathrm{w}$ państwie delegującym i w państwie zatrudnienia w odpowiednio typowym okresie (np. obrót wynoszący około $25 \%$ całkowitego obrotu w państwie delegującym może być wystarczającym wskaźnikiem, ale przypadki, w których obrót jest niższy niż 25\% wymagałyby pogłębionej analizy); okres, przez jaki przedsiębiorstwo posiada siedzibę w delegującym państwie członkowskim".

Z powyższego wynika, że „obrót wynoszący około [pogr. K.Ś.] 25\% całkowitego obrotu w państwie delegującym może być wystarczającym wskaźnikiem, ale przypadki, w których obrót jest niższy niż $25 \%$ wymagałyby pogłębionej analizy" (zob. s. 8). Wprawdzie publikacja ta nie ma waloru wiążącego, niemniej wskazuje na pewną ogólnounijną praktykę interpretowania przepisu art. 14 ust. 2 rozp. 987/2009 i z tego względu 
nie może być całkowicie pomijana $\mathrm{w}$ procesie stosowania prawa, choćby w kontekście zasady solidarności państw członkowskich. Wydaje się zatem, że kryterium $25 \%$ ustanawia co najwyżej domniemanie faktyczne dotyczące spełnienia badanego wymogu.

Z przedstawionych regulacji wynika zatem, że tylko w postanowieniach Praktycznego poradnika... pojawia się kryterium 25\% całkowitego obrotu w państwie delegującym. Sformułowanie wymogu uzyskiwania w państwie członkowskim miejsca rejestracji co najmniej $25 \%$ obrotu nie znajduje zatem oparcia ani w treści rozporządzenia 883/2004, ani rozporządzenia 987/2009, ani decyzji A2. Na gruncie rozp. 987/2009 próg 25\% odnosi się jedynie do kryteriów ilościowych branych pod uwage przy ocenie, czy w danym państwie wykonywana jest znaczna część pracy najemnej lub działalności na własny rachunek, o której mowa w art. 13 ust. 1 i 2 (zob. art. 14 ust. 8 rozporządzenia 987/2009). Stąd też odnoszenie tego progu do kryterium wielkości obrotu, uwzględnianego przy ocenie, czy dane przedsiębiorstwo prowadzi znaczną część działalności na terytorium państwa członkowskiego w kontekście możliwości delegowania pracowników należałoby uznać za nieuzasadnione, nawet $\mathrm{w}$ drodze analogii legis. Posłużenie się taką argumentacją miałoby bowiem charakter prawotwórczy.

Kryterium $25 \%$ nie da się również wyinterpretować z orzecznictwa TSUE. W pierwszej kolejności trzeba przypomnieć, że szereg przepisów dotyczących koordynacji systemów zabezpieczenia społecznego oraz treść decyzji Komisji Administracyjnej jest wyrazem uwzględnienia orzecznictwa Trybunału. I tak decyzja A2 potwierdza przede wszystkim ustalenia Trybunału zawarte $\mathrm{w}$ wyroku z dnia 10 lutego 2000 r. ${ }^{11}$ Trybunał stwierdził w nim, że przy ocenie, czy dane przedsiębiorstwo prowadzi znaczącą część działalności w państwie członkowskim, instytucja właściwa musi zbadać wszystkie [pogr. K.Ś.] kryteria charakterystyczne dla działalności prowadzonej przez przedsiębiorstwo (zob. pkt 42: „In order to determine whether an undertaking engaged in providing temporary personnel habitually carries on significant activities in the Member State in which it is established, the competent institution of that State must examine all the criteria characterizing the activities carried on by that undertaking)".

W pkt. 43 kryteria te wymienia się przykładowo, co dotyczy również obrotu. W tym świetle nie ma wątpliwości, że konieczne jest badanie wszystkich kryteriów, a nie tylko kryterium związanego z wielkością obrotu w oderwaniu od innych wymogów charakteryzujących dany przy-

${ }^{11}$ C-202/97, Fitzwilliam Executive Search Ltd, prowadzący działalność pod nazwą “Fitzwilliam Technical Services (FTS)" v. Bestuur van het Landelijk Instituut Sociale Verzekeringen, LEX, nr 82707. 
padek. Również $w$ zagranicznych opracowaniach dotyczących wyroku w sprawie Fitzwilliam podkreśla się, że Trybunał nie sformułował w nim wymogu uzyskiwania w państwie miejsca rejestracji większości dochodów, kładąc nacisk jedynie na to, czy prowadzona tam działalność jest znacząca ${ }^{12}$.

Powoływanie się zatem na wyrok Fitzwilliam jako uzasadnienie dla poglądu o konieczności stosowania wymogu uzyskiwania przez pracodawcę co najmniej $25 \%$ obrotów w państwie, w którym ma swoją siedzibę, należy uznać za nieuprawnione (zob. wyroki z dnia 16 grudnia $2014 \mathrm{r}^{13}$, jak i wcześniejsze, to jest $\mathrm{z}$ dnia 4 czerwca $2014 \mathrm{r}^{14}{ }^{14}, 6$ sierpnia $2014 \mathrm{r}^{15}$ oraz 14 października $2014 \mathrm{r}^{16}{ }^{16}$. W żadnym miejscu przedmiotowego orzeczenia Trybunału na tak określone kryterium się nie wskazuje.

Uzasadnienia dla takiego zapatrywania nie mogą stanowić także wyroki TSUE z 17 grudnia $1970 \mathrm{r} .{ }^{17}$ oraz z 9 listopada $2000 \mathrm{r} .{ }^{18} \mathrm{I}$ tak w sprawie Manpower chodziło o kwestię dopuszczalności zatrudniania pracowników tymczasowych wyłącznie $\mathrm{w}$ celu oddelegowania na terytorium innego państwa członkowskiego oraz ocenę, czy taki pracownik jest pracownikiem agencji pracy tymczasowej, czy przedsiębiorcy, do którego został on oddelegowany. Trybunał stwierdził, że dla pracownika, który został zatrudniony przez przedsiębiorstwo prowadzące działalność w danym państwie członkowskim, otrzymuje od niego wynagrodzenie, jest od niego zależny, odpowiada za działania wyrządzone przez pracownika oraz decyduje o jego zatrudnieniu (zwolnieniu), stosuje się art. 13 lit. a rozp. nr 3 dotyczącego zabezpieczenia społecznego pracowników migrujących, jeżeli na rachunek tego przedsiębiorcy wykonuje on przejściowo pracę na rzecz innego przedsiębiorcy w innym państwie członkowskim. Wyrok ten odnosił się zatem do kryteriów pozwalających na ustalenie, w jakim przypadku można uznać daną osobę za pracownika delegowanego. Z kolei w sprawie Plum, Trybunał przesądził, że nie jest możliwe delegowanie pracowników w przypadku przedsiębiorstw prowadzących w państwie delegującym wyłącznie czynności administracyjne i na tej też kwestii skoncentrowana była główna uwaga.

${ }^{12}$ F. Pennings, Introduction to European Social Security Law, Antwerp-Oxford-New York 2003, s. 110.

13 II UK 93/14, II UK 94/14 oraz II UK 95/14.

${ }^{14}$ II UK 550/13, LEX, nr 1478710 oraz II UK 565/13, LEX, nr 1475235.

${ }^{15}$ II UK 31/14.

${ }^{16}$ I UK 32/14.

17 Sprawa 35/70, Sarl Manpower przeciwko Caisse Primaire d'Assurace Maladie, ECR 1970, s. 01251; dalej jako Manpower.

18 Sprawa C-404/98, Josef Plum przeciwko Allgemeine Ortskrankenkasse Rheinland, Regionaldirektion Köln, ECR 2000, s. I-09397, dalej jako Plum. 
Rozstrzygnięcie zagadnienia sformułowanego przez pytający Sąd w sprawie III UZP 5/15, nie wywołuje zatem wątpliwości ani w świetle wykładni przepisów znajdujących zastosowanie, ani orzecznictwa TSUE. Osiągnięcie poziomu $25 \%$ może co najwyżej stwarzać domniemanie faktyczne, że przedsiębiorca „normalnie prowadzi działalność" na terytorium państwa wysyłającego w rozumieniu art. 12 ust. 1 rozp. 883/2004. Natomiast nieosiągnięcie tego obrotu wymaga analizy okoliczności określonej sprawy przy uwzględnieniu pozostałych kryteriów, jakie zostały wskazane wyżej. Wiąże się to bezpośrednio z koniecznością ustalenia normatywnej treści „normalnego prowadzenia działalności”.

\section{B. Normalne prowadzenie działalności a prowadzenie działalności znacznej}

W sprawach, w których wyłoniła się sygnalizowana wyżej rozbieżność, kluczowe było zatem ustalenie normatywnej treści wyrażenia „,normalnego prowadzenia działalności” w rozumieniu art. 12 ust. 1 rozp. 883/2004 (w sprawie III UZP 5/15 kwestia ta została niewłaściwie zasygnalizowana; nie chodziło bowiem o „prowadzenie normalnej działalności”, ale o „normalne prowadzenie działalności").

Powyższe zagadnienie było przedmiotem analizy dokonanej przez W. Gontarskiego w glosie do wyroku w sprawie Plum ${ }^{19}$. Autor ten przeprowadził bardzo staranną wykładnię wspomnianego wyrażenia i doszedł do wniosku, że warunek, według którego przedsiębiorca oddelegowujący normalnie prowadzi działalność na terytorium kraju oddelegowującego nie oznacza, że „w kraju oddelegowującym działalność przedsiębiorstwa musi mieć charakter przeważający. Nie chodzi także o kryterium ilościowe dotyczące osiąganego obrotu. Wymagane jest przede wszystkim faktyczne prowadzenie działalności w kraju oddelegowującym. Prawodawca unijny nie zastosował tutaj jakiegoś kryterium ilościowego, lecz właśnie opisowe".

Z punktu widzenia wykładni wyrażenia "normalnego prowadzenia działalności" warto zwrócić uwagę na trzy aspekty: 1) językowo-systemowy, 2) związany z relacją rozporządzenia podstawowego do wykonawczego oraz 3) funkcjonalny.

W kontekście językowo-systemowym, w pierwszej kolejności można odwołać się do innych wersji językowych art. 12 ust. 1 rozp. 883/2004. W wersji niemieckiej jest mowa o „pracodawcy, który zwyczajnie (zwykle) tam działa” (tłum. własne - oryg. "des Arbeitgebers, der gewöhnlich dort tätig ist”). Z kolei w wersji angielskiej o „pracodawcy, który zwykle (nor-

${ }^{19}$ W. Gontarski, Glosa do wyroku TS z 9 listopada 2000 r., C-404/98, LEX. 
malnie, zazwyczaj) prowadzi tam swoją aktywność" (tłum. własne - oryg. „Employer which normally carries out its activities there”). Chodzi zatem o prowadzenie działalności w państwie wysyłającym, które można zakwalifikować jako zwyczajne, na co dzień. Konkretyzacja tego wyrażenia nastąpiła w art. 14 ust. 2 rozp. 987/2009, który za „normalne prowadzenie działalności” uznaje „zazwyczaj prowadzoną znaczną część działalności, innej niż działalność związana z samym zarządzeniem wewnętrznym". Tym samym „normalne prowadzenie działalności” w ujęciu art. 12 ust. 1 rozp. 883/2004 zostało skonkretyzowane przez pryzmat działalności przeciwnej do działalności związanej z samym zarządzeniem wewnętrznym. Wynika z tego, że normalnie prowadzona działalność nie jest zatem działalnością związaną z takim zarządzaniem (kryterium negatywne), jednakże musi to być „zazwyczaj prowadzona znaczna część działalności” w rozumieniu art. 14 ust. 2 rozp. 987/2009 (w wersji niemieckiej „,andere nennenswerte Tätigkeiten" [tłum. własne „,inne godne wymienienia czynności (działania, działalność)”; z kolei w wersji angielskiej: „substantial activities" [tłum. własne - istotne działania (działalność)"]). Porównanie tych trzech wersji językowych nie przybliża jednak do ustalenia jednoznacznej treści „normalnego prowadzenia działalności”, gdyż „znaczna część działalności” (wersja polska) może być rozumiana inaczej aniżeli „inne godne wymienienia czynności” (wersja niemiecka) oraz „istotne działania” (wersja angielska). „Istotne działania” wydają się bowiem czymś więcej aniżeli „znaczna część działalności”, a tym bardziej „inne godne wymienienia czynności" (w tym przypadku wydaje się, że kryterium jest najbardziej liberalne).

Ustalenie normatywnej treści „normalnego prowadzenia działalności” w kontekście działalności znaczącej było przedmiotem rozważań w wyroku Fitzwilliam. Wyrok ten nie został opublikowany w języku polskim i nie jest również dostępny w tej wersji. Natomiast porównanie wersji niemieckiej i angielskiej prowadzi do wniosku, że mamy do czynienia $\mathrm{z}$ istotną rozbieżnością $\mathrm{w}$ tłumaczeniu. $\mathrm{W}$ wersji angielskiej stwierdza się, że przedsiębiorstwo musi normalnie prowadzić działalność w pierwszym państwie [delegującym - wtręt K.Ś.], przy czym warunek ten uznaje się za spełniony, jeśli przedsiębiorstwo stale wykonuje znaczącą [ważną - wtręt K.Ś.] działalność w państwie, w którym ma siedzibę "(pkt 40, In this regard, it is clear from the scheme of Title II of Regulation No 1408/71 and from the purpose of Article 14(1)(a) thereof that only an undertaking which habitually carries on significant [pogr. K.Ś.] activities in the Member State in which it is established may be allowed the benefit of the advantage afforded by the exception provided for by that provision)". 
Z kolei w wersji niemieckiej mowa jest tylko o konieczności prowadzenia „zwykłej [zwyczajnej - wtręt K.Ś.] działalności godnej odnotowania" (pkt. 40 - Aus dem Zusammenhang des Titels II der Verordnung Nr. 1408/71 und dem Sinn und Zweck ihres Artikels 14 Absatz 1 Buchstabe a ergibt sich, daß nur ein Unternehmen, das im Mitgliedstaat seiner Betriebsstätte gewöhnlich eine nennenswerte Geschäftstätigkeit ausübt, unter diese Bestimmung fällt).

Ta różnica widoczna jest $\mathrm{w}$ tezie drugiej sentencji (w wersji angielskiej "An undertaking engaged in providing temporary personnel normally carries on its activities in the Member State in which it is established if it habitually carries on significant activities [pogr. K.Ś.] in that State"; z kolei w wersji niemieckiej: „Ein Zeitarbeitsunternehmen übt seine Geschäftstätigkeit gewöhnlich im Mitgliedstaat seiner Betriebsstätte aus, wenn es üblicherweise nennenswerte Tätigkeiten [pogr. K.Ś.] in diesem Staat verrichtet"). Z porównania jednoznacznie wynika, że w wersji niemieckiej nie mówi się o tym, aby działalność miała charakter znaczący (ważny, znaczny).

Przy ustalaniu treści „normalnego prowadzenia działalności” pomocna jest również decyzja A2 oraz Praktyczny poradnik..., w którym wskazuje się dalej idące kryteria uznania "normalnego prowadzenia działalności” za „znaczną część działalności”. Jednocześnie stwierdza się, że konieczne jest zbadanie wszystkich kryteriów, które muszą być dostosowane do każdego konkretnego przypadku i powinny uwzględniać charakter działalności prowadzonej przez przedsiębiorstwo w państwie, w którym ma ono siedzibę. Bardzo istotne wydaje się odesłanie do "charakteru działalności prowadzonej przez przedsiębiorstwo w państwie, w którym ma ono siedzibę", ponieważ pozwala ono na określenie rodzaju (przedmiotu) działalności danego przedsiębiorstwa w kontekście przesłanki „normalnego” prowadzenia działalności „W znacznej części”. Otóż z punktu widzenia uznania prowadzenia danej działalności za „normalne" należałoby odnieść się do innych porównywanych działalności prowadzonych $\mathrm{w}$ danym państwie, zwłaszcza $\mathrm{w}$ przedsiębiorstwach, w których personel nie jest delegowany za granicę. Przedsiębiorstwa te prowadzą bowiem zarówno działalność administracyjną związaną wyłącznie z zarządzaniem wewnętrznym, jak i inną działalność (niezwiązaną z takim zarządzeniem). Kluczowe znaczenie ma więc tutaj przedmiot działalności wskazany $\mathrm{w}$ odpowiednim rejestrze oraz faktycznie prowadzony. Oznacza to, że pracodawca delegujący, normalnie prowadzi działalność, jeśli na terytorium państwa delegującego faktycznie prowadzi działalność odpowiadającą przedmiotowi działalności zgłoszonemu do odpowiedniego rejestru. W tym kontekście można byłoby zatem stwierdzić, że jest to „normalne prowadzenie działalności” w rozumieniu art. 12 ust. 1 rozp. 883/2004. 
Z kolei z punktu widzenia wzajemnej relacji rozporządzeń koordynacyjnych należałoby stwierdzić, że art. 14 ust. 2 rozp. 987/2009 reguluje kwestię dopuszczalności delegowania w sposób bardziej restrykcyjny aniżeli art. 883/2004. W wykonaniu rozporządzenia podstawowego został zatem wprowadzony dodatkowy wymóg uznania prowadzenia działalności za normalne. Chodziłoby zatem nie tyle o normalne prowadzenie działalności w państwie delegującym, ile o „znaczną częśćc takiej działalności. Stąd kryterium wymagające potwierdzenia prowadzenia działalności (innej niż zarządzania wewnętrznego) byłoby dodatkowo kwalifikowane ilościowo bądź jakościowo (,znaczący”). Wprawdzie oba akty prawne dotyczące unijnej koordynacji są rozporządzeniami (z punktu widzenia ich charakteru nie ma między nimi różnic), niemniej art. 987/2009 ma być aktem wykonującym (tak też jest w tytule) rozporządzenie 883/2004.

Normatywną treść wyrażenia "normalnego prowadzenia działalności" można również rozpatrywać w kontekście funkcji instytucji delegowania, w przypadku której ustanawia się odstępstwo od generalnej zasady ustalania ustawodawstwa według miejsca wykonywania pracy. Podstawowym celem regulacji jest usunięcie trudności, jakie pojawiałyby się w przypadku krótkotrwałego podlegania systemowi zabezpieczenia społecznego osób przemieszczających się zarobkowo w Unii Europejskiej. Przy częstych zmianach miejsca wykonywania pracy (prowadzenia działalności) podleganie różnym systemom zabezpieczenia społecznego byłoby niekorzystne dla osoby przemieszczającej się. Wiązałoby się to również z niewspółmiernym obciążaniem instytucji właściwych państw członkowskich oraz ograniczeniem swobody pracowników (por. wyrok z dnia 17 grudnia 1970 r., 35/70, Manpower). Nie ulega zatem wątpliwości, że funkcją delegowania jest umożliwienie swobodnego przemieszczania się pracowników, a szerzej świadczenia usług przez przedsiębiorców, którzy są "aktywni” nie tylko w jednym państwie członkowskim. O ile zatem usprawiedliwione jest stanowisko, że przedsiębiorca, który ogranicza swoją działalność gospodarczą w państwie delegującym wyłącznie do czynności zarządzania wewnętrznego, nie może oczekiwać, że delegowani przez niego pracownicy będą podlegać ubezpieczeniu społecznemu tego państwa, o tyle w pozostałych przypadkach konieczne jest zbadanie wszystkich warunków związanych z prowadzoną działalnością. Tak też stwierdził SN w postanowieniu w sprawie III UZP 5/15.

W powyższym świetle wydaje się, że kwestia, której nie da się jednoznacznie rozwiązać ani w drodze wykładni prawa europejskiego, ani odwołania się do orzecznictwa TSUE, dotyczy tego, czy „normalne prowadzenie działalności" w rozumieniu art. 12 ust. 1 rozp. 883/2004 musi być rozumiane jako prowadzenie działalności w znaczącej (istotnej czy znacznej) części na terytorium państwa delegującego, a jeśli tak, to w jakim 
stopniu i czy dopuszczalna jest w rozp. 987/2009 jako rozporządzeniu wykonawczym do rozp. 883/2004 taka modyfikacja przesłanek zastosowania art. 12 ust. 1 rozp. 883/2004, która prowadzi do zaostrzenia kryteriów dopuszczalności skorzystania z instytucji delegowania pracowników do wykonywania pracy na terytorium innego państwa członkowskiego, określonych w tym przepisie.

Osobiście skłaniałbym się do stanowiska, że z „normalnym prowadzeniem działalności” w rozumieniu art. 12 ust. 1 rozp. 883/2004 mamy do czynienia wówczas, gdy poza czynnościami związanymi wyłącznie z zarządzeniem wewnętrznym, przedsiębiorstwo faktycznie prowadzi na terytorium danego państwa aktywność wynikającą z zadeklarowanego przy rejestracji przedmiotu działalności. Powinna być to jednak działalność na tyle znaczna (znacząca, godna odnotowania) w rozumieniu art. 14 ust. 2 rozp. 987/2009, że nie może budzić wątpliwości, że jej głównym celem nie jest jedynie wykorzystywanie różnic $w$ obciążeniach wynikających z podlegania systemom ubezpieczenia społecznego poszczególnych państw członkowskich. Aby uznać, czy ten warunek jest spełniony konieczne jest odwołanie się do kryteriów, o których mowa w decyzji A2 oraz Praktycznym poradniku..., przy czym w razie dalszych wątpliwości należałoby uwzględnić wszystkie kryteria i charakter działalności prowadzonej przez przedsiębiorstwo w państwie, w którym ma ono siedzibę.

\section{Podsumowanie}

Przeprowadzone rozważania dowodzą, że problematyka ustalania ustawodawstwa właściwego nadal wywołuje liczne kontrowersje. Części $\mathrm{z}$ nich nie daje się jednak usunąć ani w drodze wykładni unijnych przepisów dotyczących koordynacji systemów zabezpieczenia społecznego, ani wskutek uwzględnienia orzecznictwa TSUE. Pozwala to na rozważenie skierowania na podstawie art. 267 TFUE pytań prejudycjalnych, które zostały zasygnalizowane wyżej.

\section{Bibliografia}

Gontarski W., Glosa do wyroku TS z 9 listopada 2000 r., C-404/98, LEX.

Steinmeyer H.D., Komentarz do art. 12 rozp. 883/2004 [w:] M. Fuchs, Europäisches Sozialrecht, Baden-Baden 2010.

Ślebzak K., Determination of the legislation applicable and the principle of being subject to the legislation of a single member state - selected issues, "Ius Novum” 2014, nr 2.

Ślebzak K., Kilka uwag na temat procedury ustalania ustawodawstwa właściwego w kontekście delegowania pracowników oraz wykonywania pracy na terytorium więcej aniżeli jednego państwa członkowskiego, „Ubezpieczenia społeczne. Teoria i praktyka” 2013, nr 12. 
Ślebzak K., Podleganie ubezpieczeniu społecznemu w przypadku jednoczesnego wykonywania pracy i prowadzenia działalności gospodarczej na terytorium więcej aniżeli jednego państwa członkowskiego UE, „Praca i Zabezpieczenie Społeczne” 2013, nr 11.

Ślebzak K., Ustalanie ustawodawstwa tymczasowego na podstawie rozporzadzeń 883/2004 i 987/2009, „Praca i Zabezpieczenie Społeczne” 2014, nr 7.

\title{
Selected Issues related to Interpretation of Provisions Concerning the Social Security Systems' Coordination and on the Application of the CJEU Judgments on Posting of Workers
}

\begin{abstract}
Summary
The chapter deals with selected issues related to determination of the legislation applicable in the case of posted workers in the light of the coordination of social security systems provisions in the Supreme Court's case law. This is because analysis of cases concerning the aforesaid coordination, which have been recognized by the Supreme Court and courts of law since Polish accession to the EU demonstrates that most attention was paid to the issue of determining the applicable legislation. Among the specific problem associated with such determination one can notice in particular issues of admissibility of posting civil-law-contractors and establishing the normative content of one of the key posting conditions, which is the requirement of "normally carrying out activities" within the meaning of Article 12 paragraph 1 of Regulation No 883/2004. The considerations undertaken herein show that the issue in question still causes much controversy. Some of them, however, can be removed neither by way of interpretation of EU regulations on coordination of social security systems, or as a result of the CJEU case law analysis. This allows Polish courts to consider referring questions concerning aforesaid issues for preliminary rulings pursuant to Article 267 of the Treaty on Functioning of the European Union.
\end{abstract}

